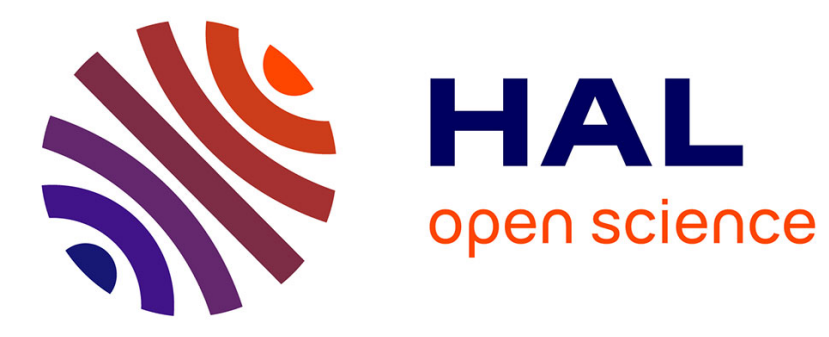

\title{
Exploring the redox balance inside gram-negative bacteria with redox-sensitive GFP
}

Joris van Der Heijden, Stefanie L. Vogt, Lisa A. Reynolds, Jorge Pena-Diaz, Audrey Tupin, Laurent Aussel, B. Brett Finlay

\section{To cite this version:}

Joris van Der Heijden, Stefanie L. Vogt, Lisa A. Reynolds, Jorge Pena-Diaz, Audrey Tupin, et al.. Exploring the redox balance inside gram-negative bacteria with redox-sensitive GFP. Free Radical Biology and Medicine, 2016, 91, pp.34-44. 10.1016/j.freeradbiomed.2015.11.029 . hal-01440762

\section{HAL Id: hal-01440762 \\ https://hal.science/hal-01440762}

Submitted on 25 May 2021

HAL is a multi-disciplinary open access archive for the deposit and dissemination of scientific research documents, whether they are published or not. The documents may come from teaching and research institutions in France or abroad, or from public or private research centers.
L'archive ouverte pluridisciplinaire HAL, est destinée au dépôt et à la diffusion de documents scientifiques de niveau recherche, publiés ou non, émanant des établissements d'enseignement et de recherche français ou étrangers, des laboratoires publics ou privés. 


\title{
Exploring the redox balance inside gram-negative bacteria with redox-sensitive GFP
}

\author{
Joris van der Heijden ${ }^{\mathrm{a}, \mathrm{b}}$, Stefanie L. Vogt ${ }^{\mathrm{a}}$, Lisa A. Reynolds ${ }^{\mathrm{a}}$, Jorge Peña-Díaz ${ }^{\mathrm{a}, \mathrm{b}}$, \\ Audrey Tupin ${ }^{\mathrm{a}}$, Laurent Aussel ${ }^{\mathrm{d}}$, B. Brett Finlay ${ }^{\mathrm{a}, \mathrm{b}, \mathrm{c}, *}$ \\ ${ }^{a}$ Michael Smith Laboratories, University of British Columbia, Vancouver, British Columbia, Canada V6T $1 Z 4$ \\ ${ }^{\mathrm{b}}$ Department of Microbiology and Immunology, University of British Columbia, Vancouver, British Columbia, Canada \\ ${ }^{\mathrm{c}}$ Department of Biochemistry and Molecular Biology, University of British Columbia, Vancouver, British Columbia, Canada \\ ${ }^{\mathrm{d}}$ Laboratoire de Chimie Bactérienne, CNRS, Institut de Microbiologie de la Méditerranée, Marseille, France
}

\begin{abstract}
Aerobic bacteria are continuously fighting potential oxidative stress due to endogenous and exogenous reactive oxygen species (ROS). To achieve this goal, bacteria possess a wide array of defenses and stress responses including detoxifying enzymes like catalases and peroxidases; however until now, the dynamics of the intra-bacterial redox balance remained poorly understood. Herein, we used redox-sensitive GFP (roGFP2) inside a variety of gram-negative bacteria to study real-time redox dynamics immediately after a challenge with hydrogen peroxide. Using this biosensor, we determined the individual contributions of catalases and peroxidases and found that each enzyme contributes more to rapid detoxification or to prolonged catalytic activity. We also found that the total catalytic power is affected by environmental conditions. Additionally, using a Salmonella strain that is devoid of detoxifying enzymes, we examined endogenous ROS production. By measuring endogenous ROS production, we assessed the role of oxidative stress in toxicity of heavy metals and antibiotics. We found that exposure to nickel induced significant oxidative stress whereas cobalt (which was previously implicated to induce oxidative stress) did not induce ROS formation. Since a turbulent debate evolves around oxidative stress as a general killing mechanism by antibiotics (aminoglycosides, fluoroquinolones and $\beta$-lactams), we measured oxidative stress in bacteria that were challenged with these antibiotics. Our results revealed that antibiotics do not induce ROS formation in bacteria thereby disputing a role for oxidative stress as a general killing mechanism. Together, our results expose how the intra-bacterial redox balance in individual microorganisms is affected by environmental conditions and encounters with stress-inducing compounds. These findings demonstrate the significant potential of roGFP2 as a redox biosensor in gramnegative bacteria to investigate redox dynamics under a variety of circumstances.
\end{abstract}

\section{Introduction}

Reactive oxygen species (ROS) plague all microorganisms that live in oxygenated environments. Either through exposure to exogenous ROS that are present in the environment or endogenous ROS, bacteria experience various degrees of oxidative stress. The term "reactive oxygen species" includes a wide variety of different oxygen radicals that all have specific reactivity to certain biomolecules and therefore can have profoundly different effects on bacteria. Parameters that are important for understanding interactions between specific ROS and bacteria, include the spatial

\footnotetext{
* Correspondence to: Michael Smith Laboratories, University of British Columbia, \#301-2185 East Mall, Vancouver, British Columbia, Canada V6T 1 Z4.

E-mail address: bfinlay@interchange.ubc.ca (B.B. Finlay).
}

localization of ROS and their respective concentration. For example, hydrogen peroxide is known to exhibit bacteriostatic actions at lower concentrations, whereas at higher concentrations, hydrogen peroxide directly interacts with DNA and proteins eventually leading to bacterial cell death $[1,2]$.

Bacteria have evolved numerous defense mechanisms against oxidative stress. An important first line of defense is the production of detoxifying enzymes including catalases, peroxidases and superoxide dismutases. Together, these enzymes convert superoxide and hydrogen peroxide into water and oxygen. After damage to intra-bacterial components, specific enzymes are produced to repair biomolecules and restore a healthy environment. Another defense strategy is to use glutathione as a buffering molecule to maintain a stable intra-bacterial redox balance. Many gram-negative bacteria use glutathione as their buffering low-molecular weight thiol for maintaining a stable redox environment $[3,4]$. 
Bacterial defenses against oxidative stress are regulated by specific transcriptional regulators e.g. OxyR or SoxR, that can "sense" oxidative stress [5]. Oxidation of these transcription factors leads to a conformational change in the protein and a corresponding change in DNA-binding properties. After oxidative stress has occurred, specific genes are switched "on" while others are switched "off". Bacterial catalases and peroxidases are examples of genes that are regulated by these transcription factors.

Despite many years of research, measuring oxidative stress inside bacteria remains challenging and a variety of experimental approaches have generated results that are often ambiguous or contradictory [6,7]. A clear example of this is illustrated by the recent debate over oxidative stress as a general antimicrobial mechanism caused by antibiotics. These discussions are fueled by conflicting data over the potential involvement of ROS in bacterial killing by antibiotics [8-13]. New analytical tools for the measurement of oxidative stress in bacteria are desperately needed to resolve some of these uncertainties. Traditional methods for analyzing oxidative stress often rely on the conversion of a fluorescent dye after interaction with specific ROS. Although these measurements can generate useful results, dyes can sometimes be affected by unrelated chemical events and their output relies on the concentration of dye inside the cell which can vary for different experimental conditions [6]. Moreover, since the conversion of fluorescent dyes is mostly irreversible, these methods provide no useful information about dynamics or detoxification of ROS inside bacteria. More recent approaches that rely on induction of oxidation-sensitive promoters that drive GFP or RFP expression have shown promise in the study of bacterial ROS encounters that happen over longer periods of time $[14,15]$. However, since ROS concentrations are known to fluctuate rapidly, there is an urgent and unmet need for the development of methods that can measure rapid redox fluctuations in the intra-bacterial redox environment in real time. Recently, we described the use of redoxsensitive GFP (roGFP2) inside Salmonella enterica Typhimurium to measure real-time changes to the intra-bacterial redox balance [16]. The roGFP2-biosensor was engineered to contain specific cysteines that form a disulfide bond upon oxidation [17]. Formation of the disulfide bond leads to a slight shift in protein conformation and the resulting oxidized and reduced isoforms of the protein can be distinguished by differential fluorescence after excitation at $405 \mathrm{~nm}$ and $480 \mathrm{~nm}$, respectively. The ratio of fluorescent signal after excitation at 405 and $480 \mathrm{~nm}$ can be used to calculate the redox potential and is a continuous measure reporting the intra-bacterial redox balance [18]. Because roGFP2 reports the redox balance by ratio-metric analysis, this system excludes variations due to differences in roGFP2 concentrations. Despite extensive use of roGFP in eukaryotic cells [3,17,19-23], this biosensor has only recently been used in bacterial systems [16,24]. Although other groups have created fusions between roGFP2 and catalyzing enzymes to speed up the response time and increase specificity [3,25], we found that the response of unaltered roGFP2 in bacteria was immediate $[16,18]$. In order to ensure sensitivity to different sources of redox stress, we used unaltered roGFP2 for our analyzes.

First, we tested roGFP2 in a variety of different gram-negative bacteria to explore differences in stress responses between bacterial species. By real-time monitoring of the intra-bacterial redox balance, we analyzed the length of time required to detoxify various amounts of hydrogen peroxide $\left(\mathrm{H}_{2} \mathrm{O}_{2}\right)$. We were able to use this information to calculate the catalytic activity of detoxifying enzymes in several bacterial species and measure the catalytic activity in different environmental conditions. We also studied the contributions of individual detoxifying enzymes in S. Typhimurium. Finally, we investigated the role of metal ions in bacterial detoxification and tested endogenous ROS generation after exposure to metal ions and antibiotics. These results provide major insights into the complex nature of redox dynamics that occurs in gram-negative bacteria.

In this manuscript, we mostly focus on disruption of the intrabacterial redox balance resulting from exposure to exogenous hydrogen peroxide or from endogenous ROS produced within bacteria. If the exact oxygen radicals in an experimental set up were known to us, we refer to these radicals by their specific names. However, when the production of endogenous ROS was examined, the cocktail of radicals was more undefined and we chose to refer to these radicals with the more broad terminology of ROS.

\section{Material and methods}

\subsection{Cloning roGFP2}

The roGFP2 gene used in this study, originated from the pRSETB vector [17]. This gene was cloned into the high copy pfpv25 vector for constitutive expression of roGFP2 in gram-negative bacteria. The pfpv25 vector carried the RpsM promoter from $S$. Typhimurium [26]. The pfpv25-roGFP2 vector was transformed into target strains and maintained by addition of $100 \mu \mathrm{g} / \mathrm{ml}$ carbenicillin [16].

\subsection{Bacterial strains and growth conditions}

The bacterial strains used in this study are listed in Table 1. Most gene deletions were made in the S. Typhimurium (12023) background. Deletions and concomitant insertion of an antibiotic resistance cassette were done using $\lambda$-red-mediated recombination as was described previously [27]. In short, mutations were moved by P22 transductions. In order to avoid outgrowth of suppressed strains, katE, katG, katN, ahpCF and tsaA, mutations were selected anaerobically on LB agar supplemented with bovine liver catalase (2000 U/plate). In some cases, antibiotic resistance cassettes were removed by using the temperature-sensitive plasmid

Table 1

Bacterial strains used in this study.

\begin{tabular}{|c|c|c|}
\hline Strain & $\begin{array}{l}\text { Relevant } \\
\text { characteristics }\end{array}$ & $\begin{array}{l}\text { Source or } \\
\text { reference }\end{array}$ \\
\hline $\begin{array}{l}\text { Salmonella enterica Typhimurium } \\
\text { (SL1344) }\end{array}$ & & [28] \\
\hline oxyR & oxyR::kan & [29] \\
\hline \multicolumn{3}{|l|}{ Salmonella enterica } \\
\hline kat- & $\Delta k a t E, \Delta k a t G$, katN::kan & [27] \\
\hline ahp- & ahpCF::kan tsaA::cat & [27] \\
\hline hpxf & $\begin{array}{l}\Delta \text { katE, } \Delta \text { katG, } \Delta k a t N \\
\Delta a h p C F, \Delta t s a A\end{array}$ & [27] \\
\hline katE & $\Delta k a t E$ & This study \\
\hline katG & $\Delta k a t G$ & This study \\
\hline katN & $\Delta$ katN & This study \\
\hline$a h p C F$ & $\triangle a h p C F$ & This study \\
\hline tsaA & $\Delta t s a A$ & This study \\
\hline Escherichia coli (DH10B) & & [30] \\
\hline Escherichia coli (BL21) & & [31] \\
\hline Salmonella enterica Typhi (TY2) & & [32] \\
\hline $\begin{array}{l}\text { Salmonella enterica Typhi } \\
\text { (ISP1820) }\end{array}$ & & [33] \\
\hline $\begin{array}{l}\text { Enteropathogenic E. coli (EPEC) } \\
\text { 0127:H6 (E2348/69) }\end{array}$ & & [34] \\
\hline $\begin{array}{l}\text { Enterohaemorrhagic } E \text {. coli (EHEC) } \\
\text { 0157:H7 (86-24) }\end{array}$ & & [35] \\
\hline Citrobacter rodentium (DBS100) & & {$[36]$} \\
\hline Yersinia pseudotuberculosis (YPIII) & & [37] \\
\hline
\end{tabular}


pCP20 carrying the FLP recombinase. Bacteria were grown in LBmedia unless otherwise stated.

\subsection{Protein purification}

roGFP2 was expressed and purified from BL21(DE3) E. coli that carried vector pet28a-roGFP2 facilitating IPTG inducible expression of roGFP2. The protein was purified as previously reported [38].

\subsection{Fluorescent protein assays}

For complete reduction purified roGFP2 was pre-incubated with $10 \mathrm{mM}$ DTT. Excess DTT was removed from the solution using Centri-Spin 20 columns (Princeton Separations Inc.). Reactions were carried out with $10 \mu \mathrm{g}$ of protein in $200 \mu \mathrm{L}$ of saline in a black, clear bottom 96 well plate (Corning). Excitation scans were carried out in a Tecan plate reader with excitation wavelengths covering 350-500 nm while emission was measured at $510 \mathrm{~nm}$. Signals for fully oxidized and fully reduced roGFP2 were obtained by adding $100 \mathrm{mM} \mathrm{H}_{2} \mathrm{O}_{2}$ and $10 \mathrm{mM}$ DTT 30 min prior to the experiment. Data were analyzed in Excel and all values were normalized to the values obtained for maximally oxidized and for fully reduced protein.

\subsection{Fluorescence measurements}

Prior to the experiments, bacteria were grown in LB-broth without addition of antibiotics unless otherwise stated. Bacteria were grown until late exponential phase $\left(\mathrm{OD}_{600}=1.0\right)$ in $125 \mathrm{~mL}$ flasks with aeration. For analysis of stationary phase bacteria, an overnight culture was used. During growth of hpxf S. Typhimurium cultures, bovine liver catalase $(1000 \mathrm{U} / \mathrm{ml})$ was added to the medium. Bacteria were spun down and washed in saline $(0.9 \% \mathrm{w} / \mathrm{v})$ before resuspension of bacterial cultures at density $\mathrm{OD}_{600}=2$ in saline solution. To check if bacterial numbers for each experiment were similar, these samples were additionally plated out for CFU counting. $100 \mu \mathrm{L}$ of culture was loaded into pre-warmed 96 well black, clear bottom plates (COSTAR). The redox balance inside bacteria was analyzed by measuring fluorescence after excitation at $405 \mathrm{~nm}$ and $480 \mathrm{~nm}$ while emission was measured at $510 \mathrm{~nm}$ [16]. Before challenge with $\mathrm{H}_{2} \mathrm{O}_{2}$, the intra-bacterial redox balance was determined for $25 \mathrm{~min}$ to ensure equal start positions. Bacteria were challenged with $0 \mathrm{mM}$, $20 \mu \mathrm{M}, 40 \mu \mathrm{M}, 60 \mu \mathrm{M}, 80 \mu \mathrm{M}, 100 \mu \mathrm{M}, 150 \mu \mathrm{M}, 200 \mu \mathrm{M}, 400 \mu \mathrm{M}$, $600 \mu \mathrm{M}, 800 \mu \mathrm{M}, 1 \mathrm{mM}, 2 \mathrm{mM}, 3 \mathrm{mM}, 4 \mathrm{mM}, 5 \mathrm{mM}, 7.5 \mathrm{mM}, 10 \mathrm{mM}$ or $100 \mathrm{mM}$ (oxidized control) of $\mathrm{H}_{2} \mathrm{O}_{2}$ As a reducing control $1 \mathrm{mM}$ DTT was added. Background signals from non-fluorescent bacteria were obtained in the same experiment. The 405/480 ratio values were normalized to the $405 / 480$ ratio values for maximum oxidized and reduced conditions (minimum value 0.1 and maximum value 1.0). For the experiment with chelators, 25 mM EGTA (ethylene glycol tetraacetic acid, Sigma-Aldrich) or 25 mM EDTA (ethylenediaminetetraacetic acid, Sigma-Aldrich) was added $25 \mathrm{~min}$ prior to the challenge with $\mathrm{H}_{2} \mathrm{O}_{2}$.

\subsection{Calculation of velocity and determination of Michaelis Menten correlation}

The total detoxification time was determined for each $\mathrm{H}_{2} \mathrm{O}_{2}$ concentration that was used for the challenge. The detoxification time was used for calculation of the reaction velocity $v(\mu \mathrm{M} / \mathrm{s})$ using Eq. (1).

$v=\frac{\left[\mathrm{H}_{2} \mathrm{O}_{2}\right]_{\text {challenge }} * \frac{1}{2}}{t_{\text {detox }}}$
With this equation, the velocity was determined as a function of $\left[\mathrm{H}_{2} \mathrm{O}_{2}\right]$. The average $\left[\mathrm{H}_{2} \mathrm{O}_{2}\right]$ throughout the experiment is assumed to be half of the concentration that is used to challenge the bacteria $\left(\left[\mathrm{H}_{2} \mathrm{O}_{2}\right]_{\text {challenge }}\right)$. The detoxification time $t_{\text {detox }}(\mathrm{s})$ is determined experimentally. The velocity was plotted against the $\left[\mathrm{H}_{2} \mathrm{O}_{2}\right]$ and a Michaelis Menten correlation was fitted against the resulting data. The standard Michaelis Menten equation is shown below.

$v=\frac{V_{\text {max }} *\left[\mathrm{H}_{2} \mathrm{O}_{2}\right]}{\mathrm{K}_{\mathrm{M}}+\left[\mathrm{H}_{2} \mathrm{O}_{2}\right]}$

\subsection{Measurement of endogenous ROS production}

For the measurement of endogenous ROS production, the $h p x f$ $S$. Typhimurium strain was used which is devoid of detoxifying enzymes. This strain was grown to late exponential phase in LBbroth supplemented with bovine liver catalase $(1000 \mathrm{U} / \mathrm{ml})$. All measurements were done in saline over $100 \mathrm{~min}$ or $10 \mathrm{~h}$ depending on the experiment. The 405/480 ratio values were normalized to the maximum reduced ( $1 \mathrm{mM}$ DTT addition) and maximum oxidized ( $100 \mathrm{mM} \mathrm{H} \mathrm{H}_{2}$ addition) values as was done previously. The normalized ratio at the start of the experiment was set to 0 . To determine oxidative stress caused by metal ions, $1 \mathrm{mM}$ sodium chloride, $1 \mathrm{mM}$ potassium chloride, $1 \mathrm{mM}$ lithium chloride, $1 \mathrm{mM}$ rubidium chloride, $1 \mathrm{mM}$ magnesium chloride, $1 \mathrm{mM}$ calcium chloride, $1 \mathrm{mM}$ zinc chloride, $1 \mathrm{mM}$ cobalt chloride or $1 \mathrm{mM}$ nickel chloride was added to the saline solution. For determination of endogenous ROS production after exposure to antibiotics, $12.5 \mu \mathrm{g} / \mathrm{ml}$ gentamicin, $25 \mu \mathrm{g} / \mathrm{ml}$ streptomycin, $25 \mu \mathrm{g} / \mathrm{ml}$ kanamycin, $1 \mu \mathrm{g} / \mathrm{ml}$ ciprofloxacin, $50 \mu \mathrm{g} / \mathrm{ml}$ cefotaxime or $25 \mu \mathrm{g} / \mathrm{ml}$ ampicillin was added to bacterial cultures.

\section{Results and discussion}

\subsection{Comparing redox dynamics in different bacterial species}

In this study, we expressed roGFP2 in Escherichia coli (DH10B), E. coli (BL21), S. Typhimurium (12023), enteropathogenic E. coli (EPEC) 0127:H6 (E2348/69), enterohaemorrhagic E. coli (EHEC) O157:H7 (E86-24), Salmonella enterica Serovar Typhi (S. Typhi ISP1820), S. Typhi (TY2), Citrobacter rodentium (DBS100), Yersinia pseudotuberculosis (YPIII) and S. enterica Serovar Typhimurium (S. Typhimurium SL1344) and we individually challenged each bacterial species with varying amounts of $\mathrm{H}_{2} \mathrm{O}_{2}$ to analyze the catalytic power of their detoxifying enzymes (Fig. 1A). For this, bacterial cultures were grown to late exponential phase in M9 minimal media and the Michaelis Menten correlation was determined for overall detoxification of $\mathrm{H}_{2} \mathrm{O}_{2}$ (Figs. 1B-2K). The slope of the Michaelis Menten correlation generates information about how fast detoxification occurs whereas the $V_{\max }$ tells us what the maximum capacity is of detoxifying enzymes.

In each experiment we used $2.6 \cdot 10^{8}$ bacteria and this number remained constant throughout each experiment. These results show that roGFP2 can be used in a variety of different bacteria and that substantial differences in detoxifying power exist between closely related bacterial species and even between bacterial strains.

\subsection{How do environmental conditions affect detoxification of hydrogen peroxide?}

To examine how environmental conditions would impact the velocity $(\nu)$ by which catalases and peroxidases detoxify $\mathrm{H}_{2} \mathrm{O}_{2}$, we 
A

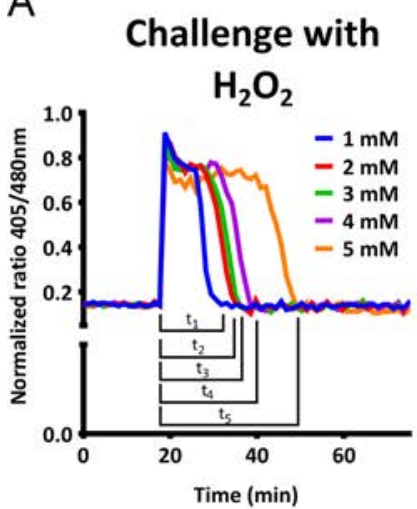

$\mathrm{E}$

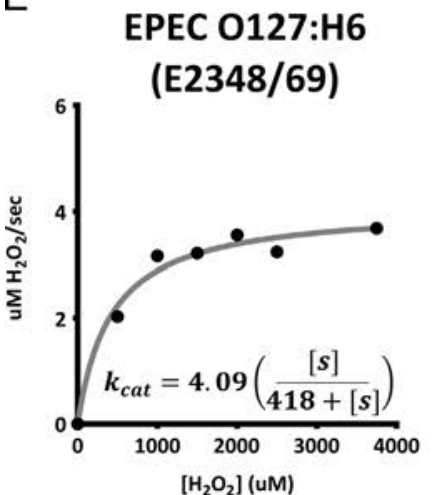

I

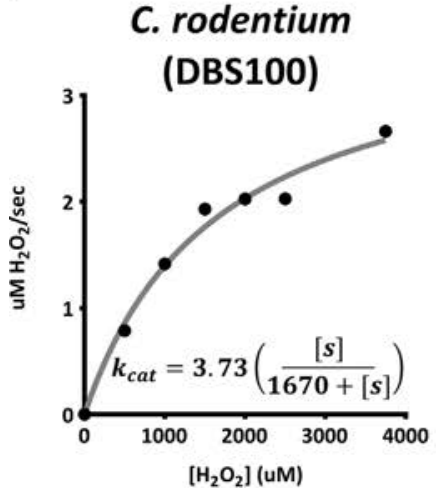

B E. coli

(DH10B)

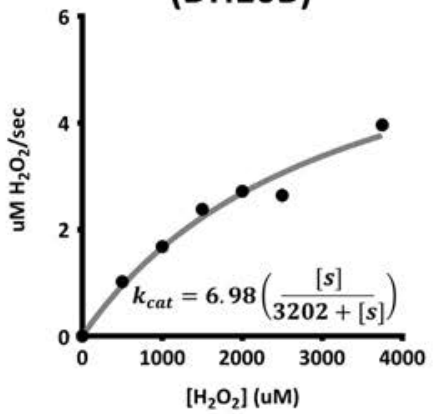

$\mathrm{F}$

EHEC 0157:H7

(E86-24)

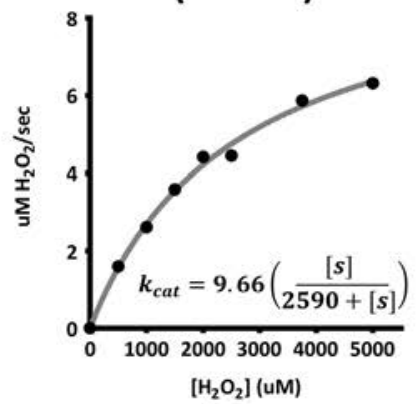

$\mathrm{J}$

Y. pseudotuberculosis (YPIII)

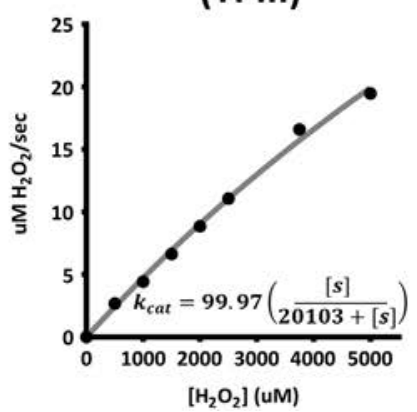

C E. coli (BL21)

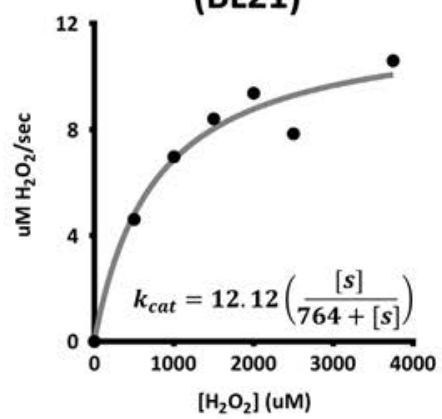

G

S. Typhi

(ISP1820)

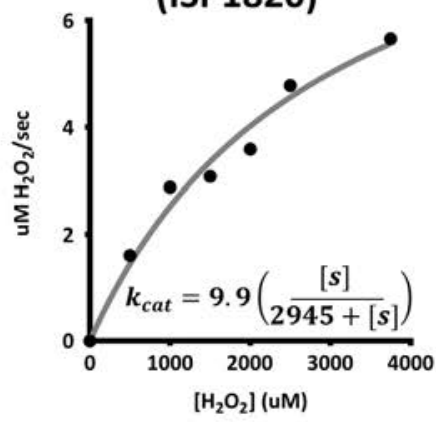

$\mathrm{H}$
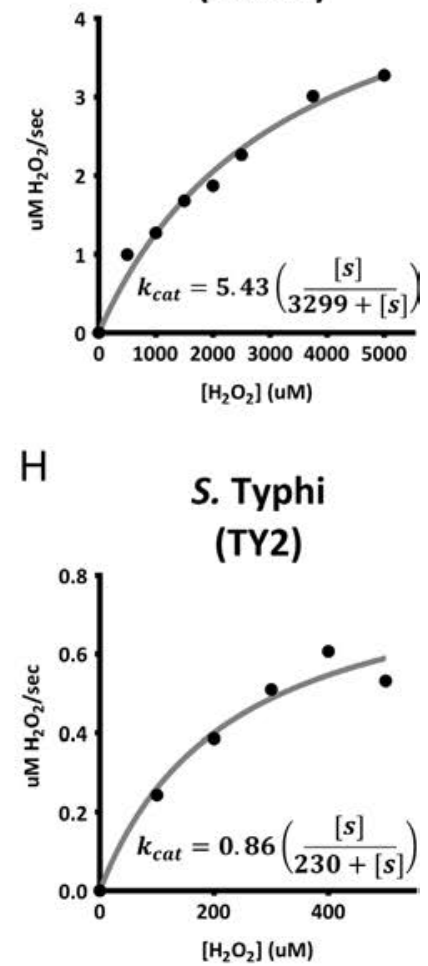

S. Typhimurium

(12023)

$\left[\mathrm{H}_{2} \mathrm{O}_{2}\right]$ (uM)

\section{S. Typhi}

(TY2)

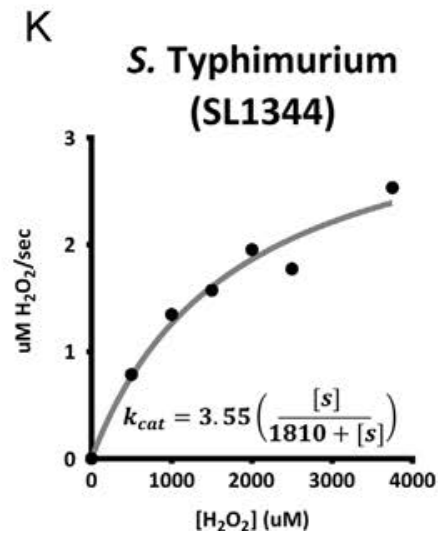

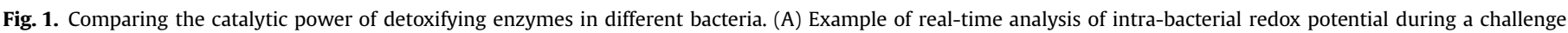

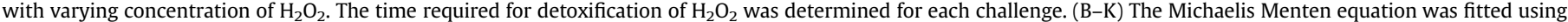

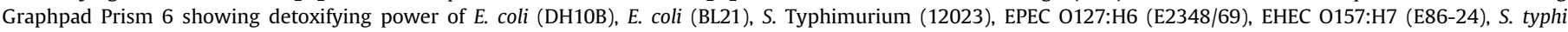

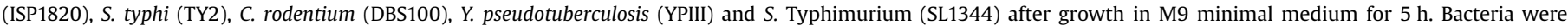

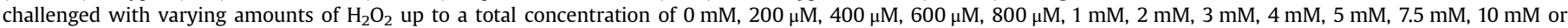
$100 \mathrm{mM}$ of $\mathrm{H}_{2} \mathrm{O}_{2}$. Each value represents the average of four technical replicates. Each assay was performed in at least two separate experiments.

examined detoxification after growth in different growth medias, and at different $\mathrm{pH}$ and temperatures. For these experiments, S. Typhimurium $(12,023)$ was used. Significant differences in detoxification kinetics were observed after growth in various growth media (Fig. 2A). In M9 minimal media (M9) and Heart and Brain media (H\&B), initial detoxification was slower than for bacteria grown in LB but the maximal capacity of detoxifying enzymes was higher. In Super Optimized Broth (SOB), detoxification by $S$. Typhimurium was slower overall and a lower maximal capacity was found.

A similar approach was used to examine the effect of $\mathrm{pH}$. After growth in LB, $S$. Typhimurium was resuspended in phosphate buffered saline (PBS) at different pHs and the Michaelis Menten correlation for $\mathrm{H}_{2} \mathrm{O}_{2}$ detoxification was determined (Fig. 2B).
Detoxification was fastest and most efficient in $\mathrm{pH} 7$ while a shift away from $\mathrm{pH} 7$ in either direction decreased the velocity of detoxification. These results indicate that $S$. Typhimurium's detoxifying enzymes have evolved to be most efficient at $\mathrm{pH} 7$.

To test the effect of temperature, we challenged $S$. Typhimurium with $\mathrm{H}_{2} \mathrm{O}_{2}$ at temperatures of $25^{\circ} \mathrm{C}, 37{ }^{\circ} \mathrm{C}$ and $42{ }^{\circ} \mathrm{C}$ (Fig. 2C). The velocity of detoxification by $\mathrm{S}$. Typhimurium at $37^{\circ} \mathrm{C}$ was greater for smaller amounts of $\mathrm{H}_{2} \mathrm{O}_{2}$ whereas bacteria at $25{ }^{\circ} \mathrm{C}$ detoxified $\mathrm{H}_{2} \mathrm{O}_{2}$ slower but had greater maximal capacity for detoxification. The velocity of detoxification by $S$. typhimurium at $42{ }^{\circ} \mathrm{C}$ was lower which is surprising since higher temperatures often speed up enzyme kinetics. The $\mathrm{V}_{\max }$ at $42^{\circ} \mathrm{C}$ was also reduced.

All living organisms need to rapidly adapt to their environment. 
A

\section{Different growth}

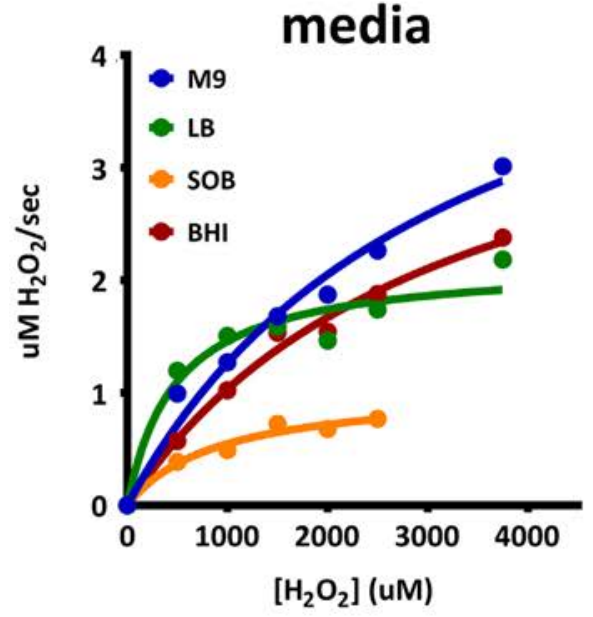

C

\section{Temperature}

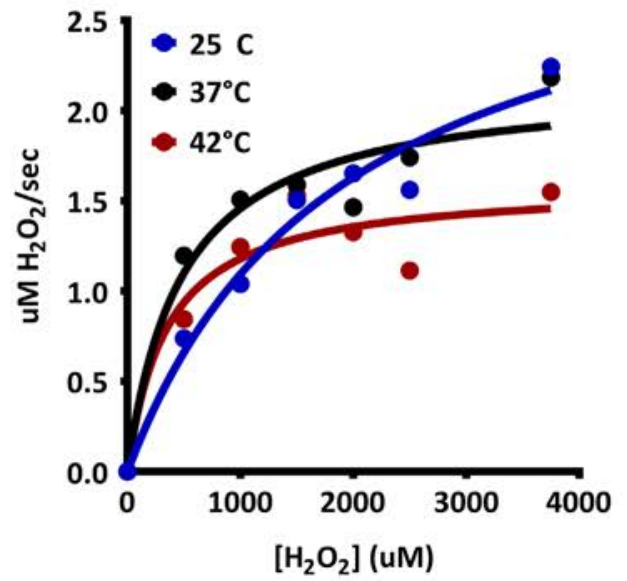

E

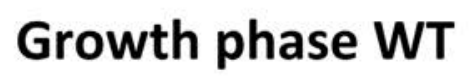

(log vs stat)

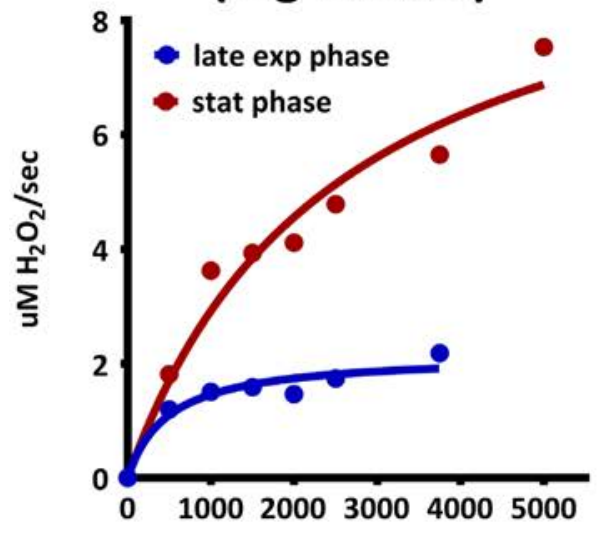

[ $\mathrm{H}_{2} \mathrm{O}_{2}$ ] (uM)
B

\section{Different pH}

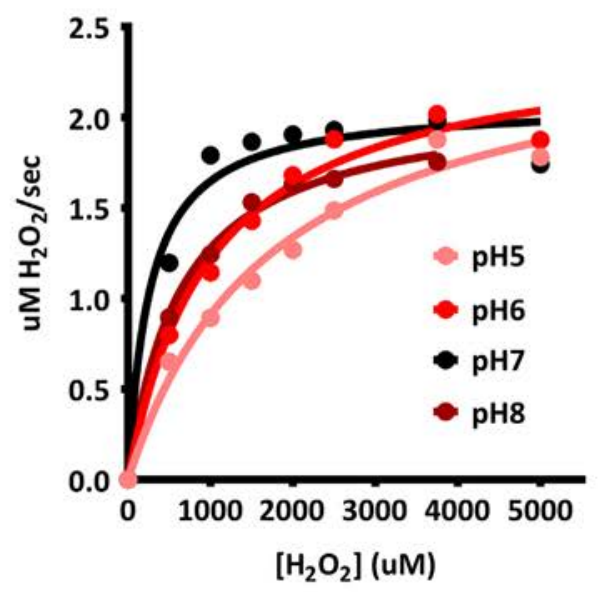

D

\section{Naive vs primed}

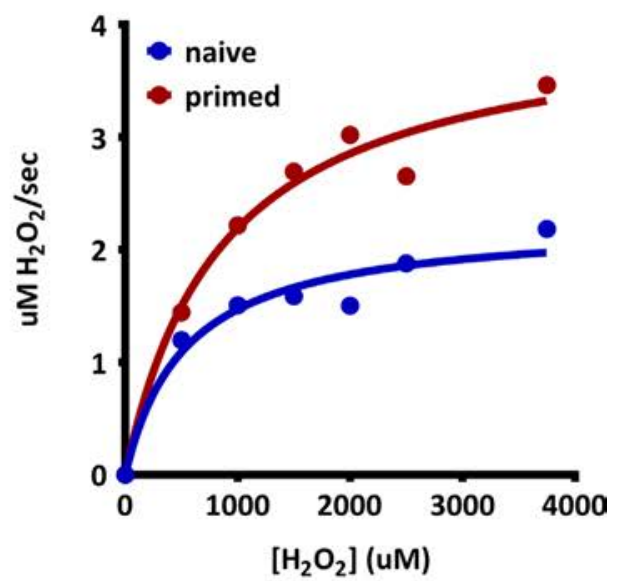

F

\section{Growth phase hpxf}

(log vs stat)

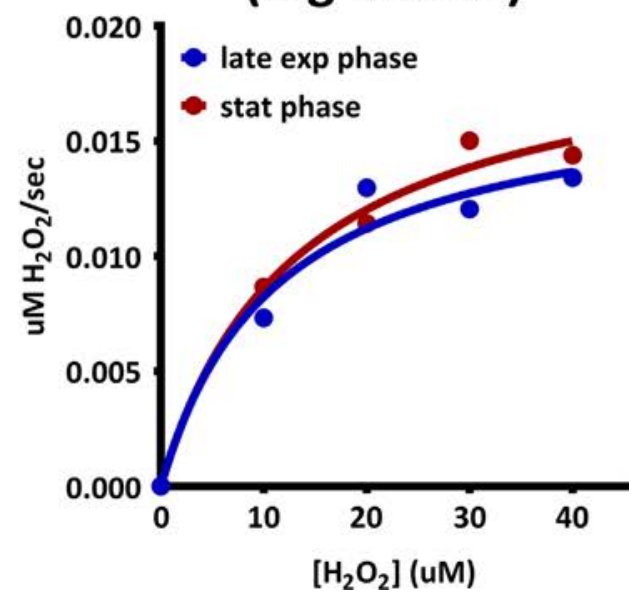

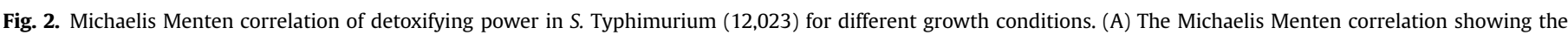

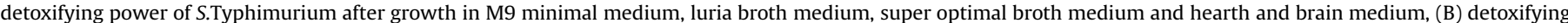

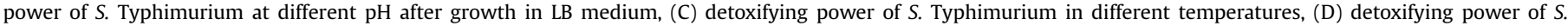

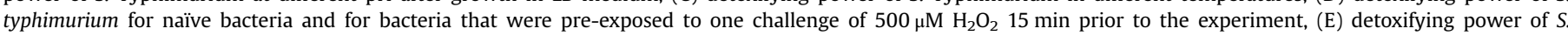

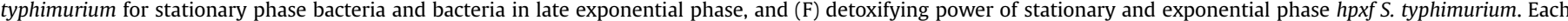
value represents the average of four technical replicates. Each assay was performed in at least two separate experiments. 
A

\section{Naive vs primed timelapse}

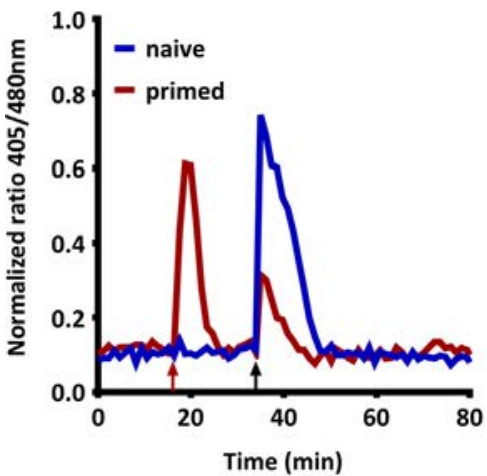

B

\section{Naive vs primed (+ chloramphenicol)}

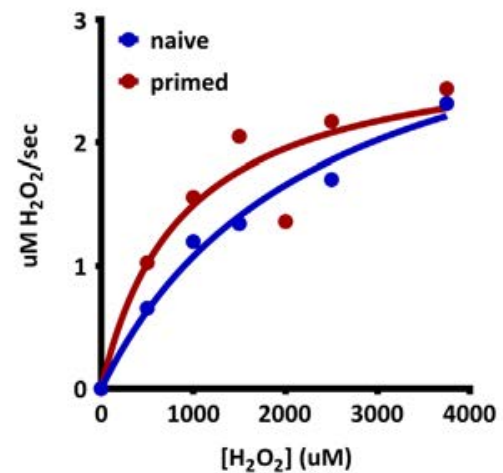

C

\section{Naive vs primed (oxyR background)}

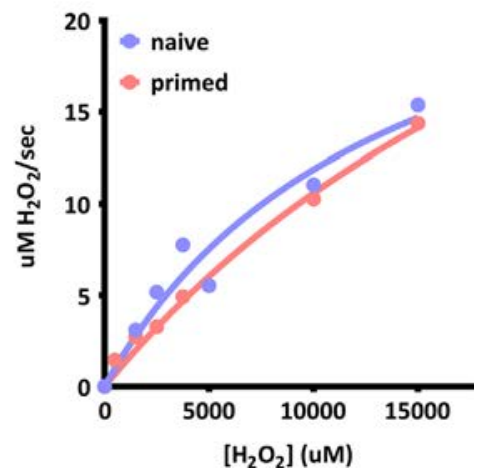

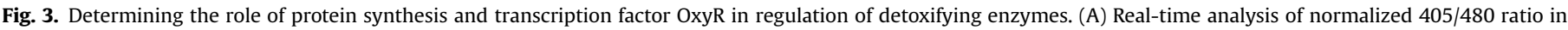

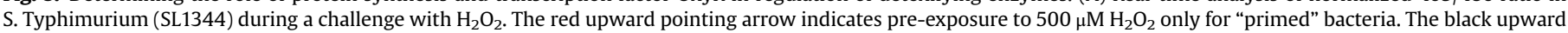

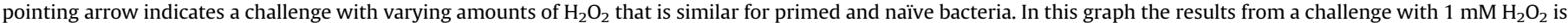

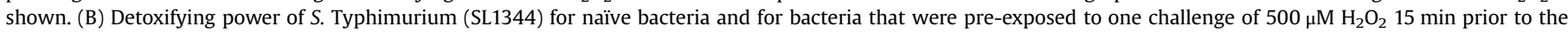

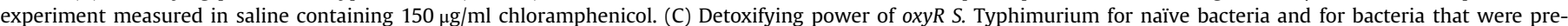

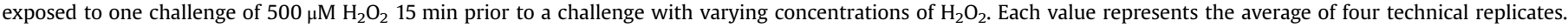

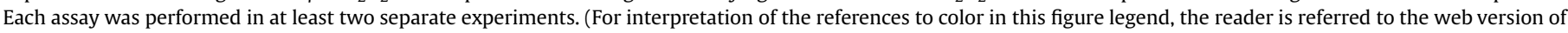
this article.)

To test if pre-exposure to $\mathrm{H}_{2} \mathrm{O}_{2}$ helped bacteria become more efficient at detoxification of $\mathrm{H}_{2} \mathrm{O}_{2}$, we challenged $S$. Typhimurium with $500 \mu \mathrm{M} \mathrm{H}_{2} \mathrm{O}_{2}$ prior to a challenge with varying concentrations of $\mathrm{H}_{2} \mathrm{O}_{2}$ (Fig. 2D). We found that pre-exposed ("primed") bacteria were significantly faster at detoxification then naïve bacteria. In addition, primed bacteria had a higher maximal capacity for detoxifying $\mathrm{H}_{2} \mathrm{O}_{2}$ showing that bacteria rapidly adapt to oxidizing environments.

The above experiments were all performed with bacteria grown to late exponential phase. It is well established that bacteria in stationary phase express different genes than organisms that are still in exponential growth phase [39]. To investigate if stationary phase bacteria were more or less efficient at detoxification, $S$. Typhimurium was grown overnight and the Michaelis Menten correlation was determined (Fig. 2E). We found that stationary phase bacteria were significantly better at detoxifying $\mathrm{H}_{2} \mathrm{O}_{2}$ than bacteria in exponential growth phase. This advantage was due to catalases and/or peroxidases since $h p x F$ S. Typhimurium (which are devoid of catalases and peroxidases) was not more efficient at detoxification after growth to stationary phase (Fig. 2F). All Michaelis Menten constants from the experiments in Fig. 2 are shown in Table S1 in Supplementary Material.

In order to investigate if the differences in catalytic activity that we observed for growth in different media, $\mathrm{pH}$ conditions, temperatures and different growth phases were a direct result of bacterial killing, we determined bacterial survival after exposure to $4 \mathrm{mM}$ or $8 \mathrm{mM} \mathrm{H}_{2} \mathrm{O}_{2}$ (Fig. 1 in Ref. [40]). In these experiments we did not find that bacterial killing was the reason for the observed differences in Michaelis Menten kinetics. However, we found that bacteria grown in M9 minimal medium and SOB medium showed decreased survival after exposure to $\mathrm{H}_{2} \mathrm{O}_{2}$. Interestingly, the bacteria grown in M9 medium showed the highest $V_{\max }$ value in our roGFP2 experiments. We speculate that the higher $V_{\max }$ could result from an increased $\mathrm{H}_{2} \mathrm{O}_{2}$ influx over perforated membranes of dead bacteria compared to lower $\mathrm{H}_{2} \mathrm{O}_{2}$ influx over intact membranes of living bacteria. Another consideration is that the survival of bacteria after $\mathrm{H}_{2} \mathrm{O}_{2}$ exposure depends greatly on their fitness. Although detoxifying enzymes do contribute to bacterial fitness, many other parameters play a role in this and currently, bacterial fitness is difficult to quantify. Dramatic differences in catalytic activity do translate to bacterial fitness as is shown by the results in Fig. 1D in Ref. [40]. In these results, the dramatic difference in catalytic activity between stationary phase bacteria and bacteria that were grown to exponential phase correlates with bacteria survival after exposure to $\mathrm{H}_{2} \mathrm{O}_{2}$.

\subsection{Pre-exposure to $\mathrm{H}_{2} \mathrm{O}_{2}$ primes bacteria for more efficient detoxification.}

In Fig. 2D we show that bacteria rapidly become more efficient at detoxifying $\mathrm{H}_{2} \mathrm{O}_{2}$ after pre-exposure to $500 \mu \mathrm{M}$ of $\mathrm{H}_{2} \mathrm{O}_{2}$ compared to naïve bacteria. Fig. $4 \mathrm{~A}$ shows a visualization of the realtime analysis of the intra-bacterial redox balance in $S$. Typhimurium for primed (red) and naïve (blue) bacteria after a challenge with $1 \mathrm{mM} \mathrm{H}_{2} \mathrm{O}_{2}$ (Fig. 3A). Primed $S$. Typhimurium bacteria were consistently faster than naïve bacteria at detoxifying $\mathrm{H}_{2} \mathrm{O}_{2}$. To investigate if this adaptation was due to increased production of detoxifying enzymes (induced by the first exposure to $\mathrm{H}_{2} \mathrm{O}_{2}$ ), we compared detoxification in primed and naïve bacteria while inhibiting protein synthesis (Fig. 3B). For this, $150 \mu \mathrm{g} / \mathrm{ml}$ chloramphenicol was added prior to pre-exposure to $\mathrm{H}_{2} \mathrm{O}_{2}$. We found that addition of chloramphenicol blocked the ability to prime bacteria, indicating that bacterial adaptation requires protein synthesis.

OxyR is a major transcriptional regulator that can "sense" oxidative stress through formation of an oxidation-sensitive disulfide bond [5]. To test if OxyR was driving transcription and subsequent protein synthesis allowing adaptation of $S$. Typhimurium to $\mathrm{H}_{2} \mathrm{O}_{2}$, we compared detoxification in WT S. Typhimurium and oxyR $S$. Typhimurium after pre-exposure to $500 \mu \mathrm{M} \mathrm{H}_{2} \mathrm{O}_{2}$ (Fig. 3C). The rapid adaptation that was previously observed in primed bacteria was absent in the primed oxyR mutant indicating that OxyR is driving rapid protein synthesis to prime bacteria for subsequent $\mathrm{H}_{2} \mathrm{O}_{2}$ exposure. These results highlight that adaptability of bacteria to $\mathrm{H}_{2} \mathrm{O}_{2}$ is driven by rapid protein synthesis that is regulated by OxyR.

\subsection{Determining the contribution of individual catalases and peroxidases}

To gain more insight into the contribution of each detoxifying enzyme individually, we tested the detoxifying activity in a variety 
A
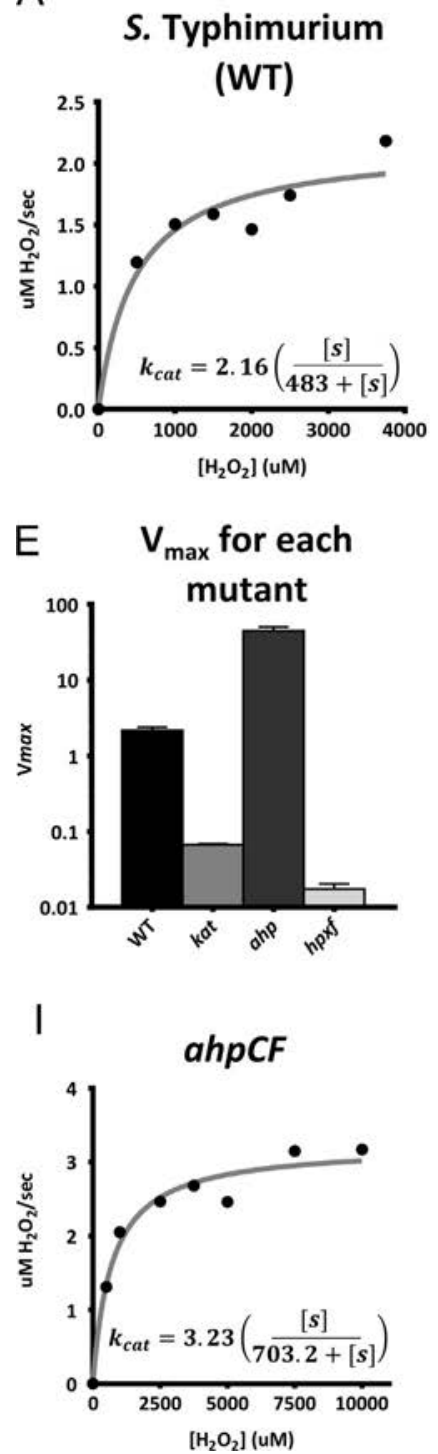

B

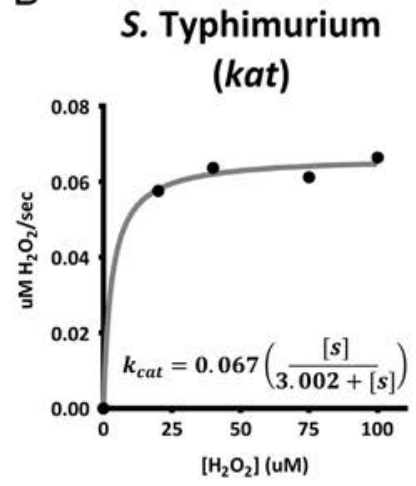

$\mathrm{F}$

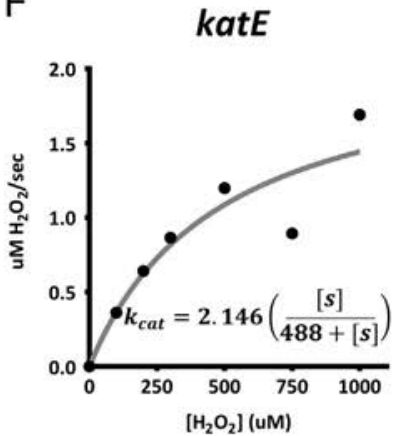

$\mathrm{J}$

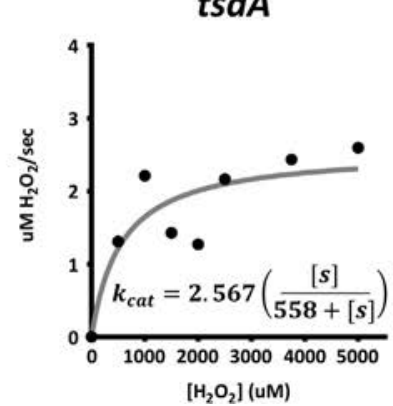

C

S. Typhimurium (ahp)

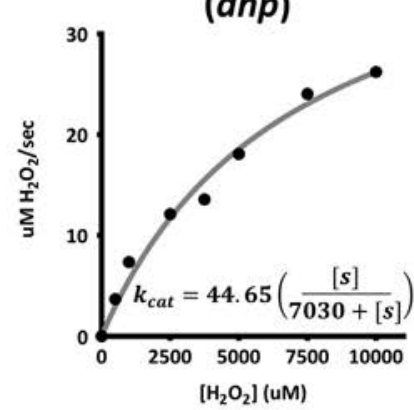

G

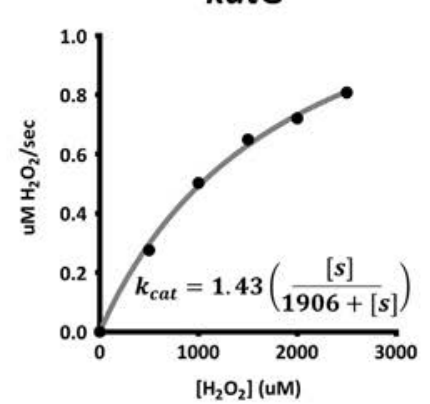

S. Typhimurium (hpxf)

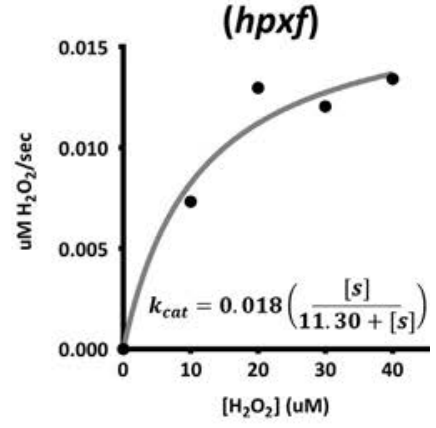

$\mathrm{H}$

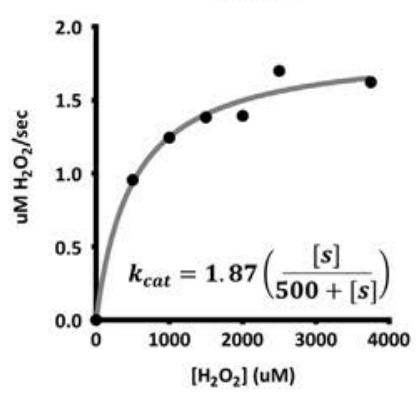

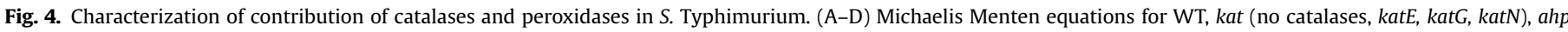

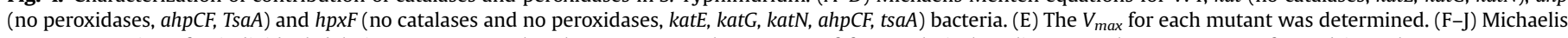

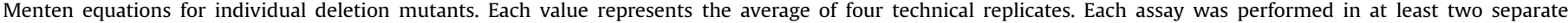
experiments.

of $S$. Typhimurium deletion mutants. First, we determined the Michaelis Menten correlations for WT, kat- (no catalases), ahp- (no peroxidases) and for $h p x f$ (no catalases or peroxidases) mutants (Fig. 4A-D). We observed attenuated detoxification after deletion of all catalases (kat-) or after deletion of catalases and peroxidases ( $h p x f$ ). In contrast, deletion of peroxidases ( $a h p-)$ led to increased detoxifying power (Fig. 4C). The dramatically increased detoxifying power in the ahp- mutant suggests a scenario in which $S$. Typhimurium over-compensates for the loss of peroxidases. The corresponding $V_{\max }$, of all mutants were also compared (Fig. $4 \mathrm{E}$ ).

To further assess the contribution of individual enzymes, we measured the detoxifying power of single deletion mutants in katE, katG, katN, ahpCF and tsaA (Fig. 4F-J). Deletion of individual catalases affected efficiency of $\mathrm{H}_{2} \mathrm{O}_{2}$ detoxification more than deletion of individual peroxidases. This is in agreement with previous findings that show that catalases are the main scavengers of higher doses of $\mathrm{H}_{2} \mathrm{O}_{2}$, despite favorable kinetics of peroxidase detoxification [41]. This can be explained by the fact that peroxidases use NADH for detoxification of $\mathrm{H}_{2} \mathrm{O}_{2}$. Previously, it was shown that the cell cannot provide enough NADH for peroxidases to rapidly degrade large amounts of $\mathrm{H}_{2} \mathrm{O}_{2}$ [41]. Thus, peroxidases are more efficient scavengers of $\mathrm{H}_{2} \mathrm{O}_{2}$ at lower doses whereas catalases play a bigger role in detoxification of higher doses of $\mathrm{H}_{2} \mathrm{O}_{2}$. Since we used higher doses of $\mathrm{H}_{2} \mathrm{O}_{2}$ in this study, we found that catalases were more important than peroxidases for detoxification. Although catalases are thought to have redundant functions, these measurements also showed unique properties for each catalase. These findings showed that KatE and KatN were more important for increasing the $\mathrm{V}_{\max }$ whereas KatG played a bigger role in rapid detoxification of $\mathrm{H}_{2} \mathrm{O}_{2}$.

\subsection{Measuring endogenous ROS production}

Since the roGFP2 redox sensor reports oxidative stress irrespective of the source, we extended our analysis to measuring endogenous ROS production. In particular, if the hpxf S. Typhimurium mutant is used which lacks catalases and peroxidases, endogenous ROS production can be examined without interference from rapid detoxification. Endogenous ROS production often results from bacterial respiration but there may be other sources of endogenous ROS production which 
A

\section{ROS formation in different media}

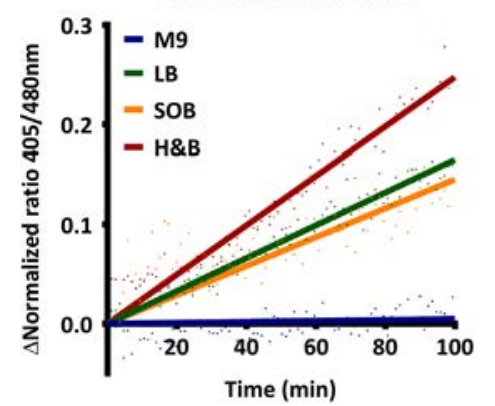

B

ROS formation during different growth phases

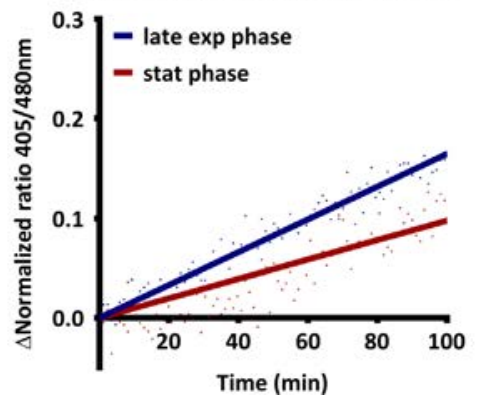

C

\section{ROS formation in different temperatures}

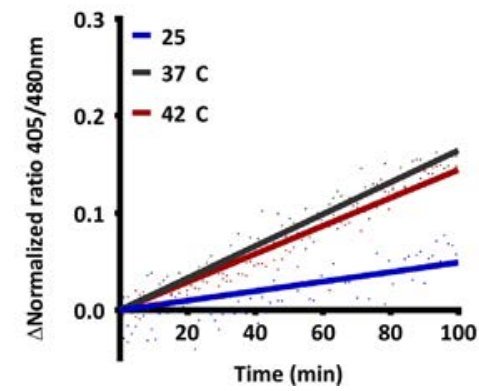

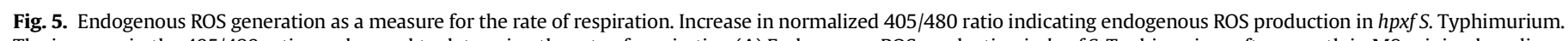

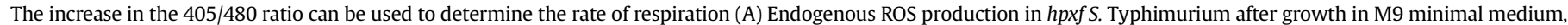

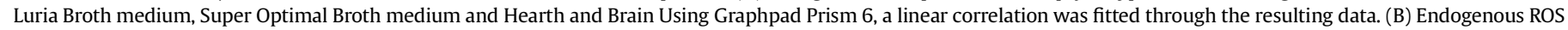

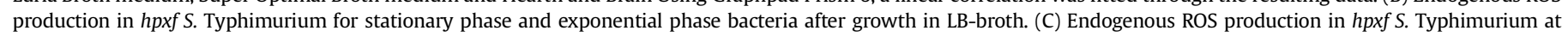
different temperatures. Each value represents the average of four technical replicates. Each assay was performed in at least two separate experiments.

A

\section{Detoxification and chelators}

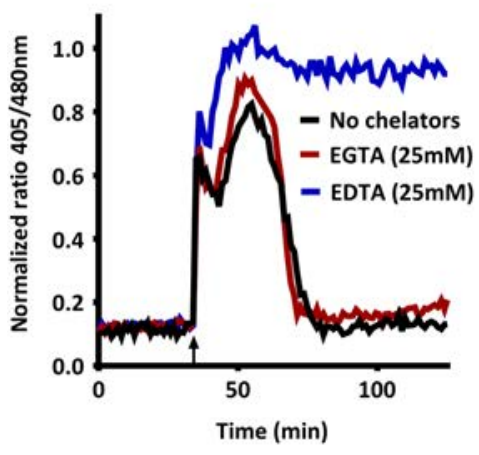

D

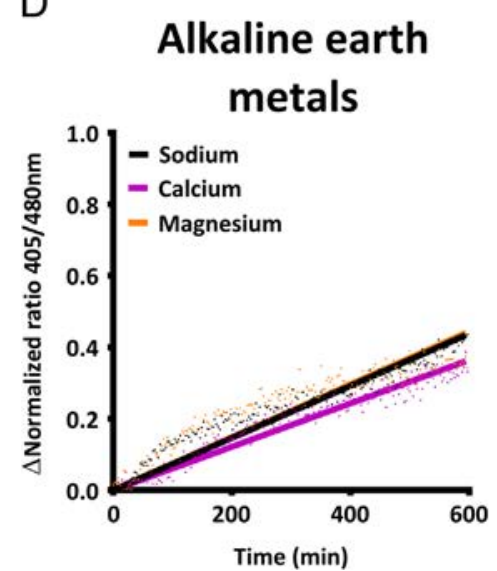

B
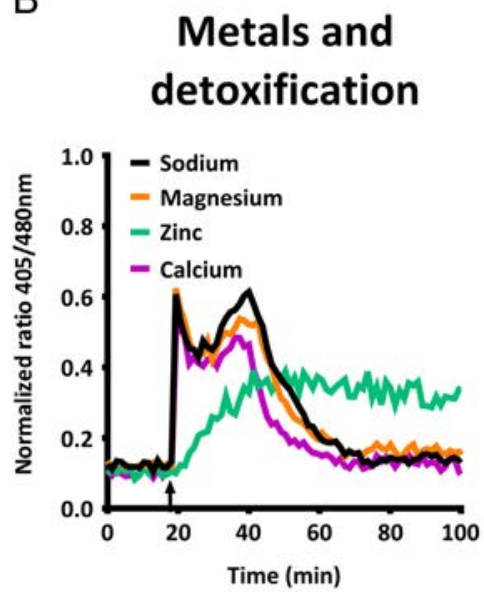

E

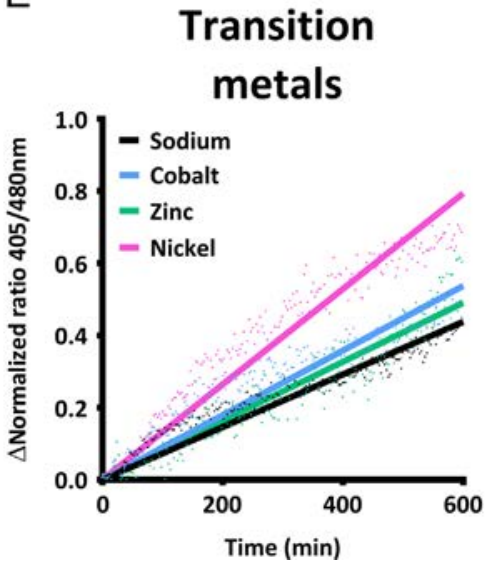

C

\section{Alkali metals}

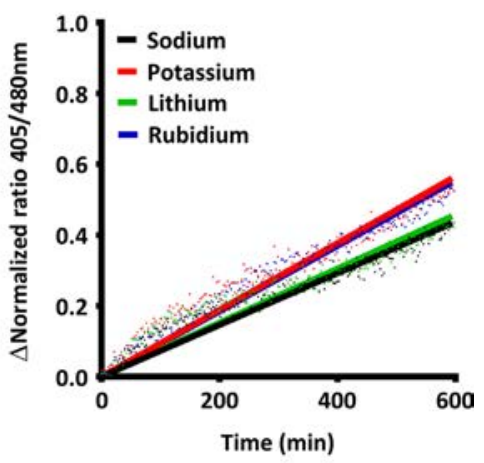

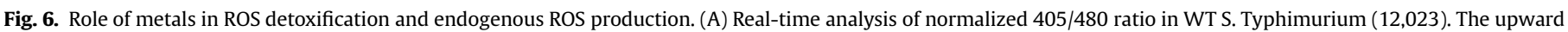

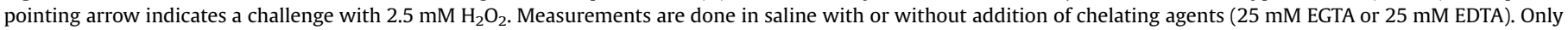

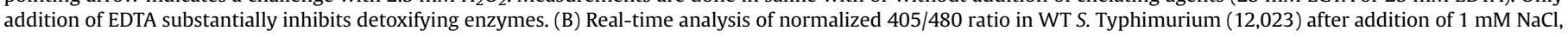

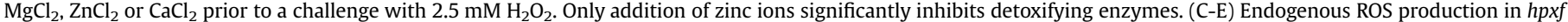

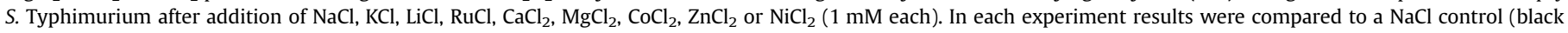

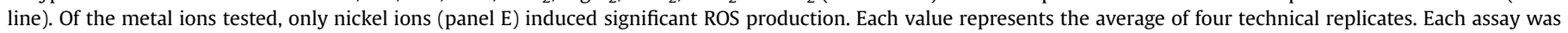
performed in at least two separate experiments.

could play a role in bacterial toxicity $[42,43]$. First, we tested endogenous ROS production after growth in different growth media (Fig. 5A). The change in the normalized 405/480 ratio over the course of the experiment was used to determine the endogenous ROS production. We found that the rate of ROS production was similar for bacteria grown in rich (LB or SOB) medium whereas almost no ROS were produced in bacteria grown in minimal (M9) medium. S. Typhimurium grown in Heart Brain Infusion (HBI) medium (fairly rich medium) produced high levels of ROS over the course of the experiment. A similar approach was used to compare stationary phase 
S. Typhimurium with bacteria grown to exponential growth phase. Stationary phase bacteria were found to have lower endogenous ROS production than exponential phase bacteria (Fig. 5B). To confirm that the endogenous ROS production we measured using roGFP2 was in accordance with results obtained using more established methods, we measured the output of $\mathrm{H}_{2} \mathrm{O}_{2}$ by stationary phase bacteria and by bacteria that were grown to exponential growth phase with the Amplex Red assay (Fig. 2. in Ref. [40]). The output of $\mathrm{H}_{2} \mathrm{O}_{2}$ correlates with the amount of endogenous ROS that is produced and with the Amplex Red assay, we confirmed our data obtained using the roGFP2 biosensor.

When comparing the effect of temperature on the rate of respiration we found that bacteria kept at $37{ }^{\circ} \mathrm{C}$ or $42{ }^{\circ} \mathrm{C}$ showed a similar accumulation of ROS whereas lowering the temperature to $25{ }^{\circ} \mathrm{C}$ slowed ROS production in S. Typhimurium (Fig. 5C). These results show that roGFP2 inside bacteria can be used for comparing endogenous ROS formation and that environmental conditions significantly impact the rate of ROS production.

\subsection{Metals and oxidative stress}

Many enzymes, including catalases in S. Typhimurium require heme or manganese ions for their activity [44]. Without metal ions, these enzymes cannot function properly. In contrast, heavy metals have toxic effects on algae, molds, spores, fungi, prokaryotic and eukaryotic microorganisms in a process that is referred to as the oligodynamic effect [45]. Although mechanisms that lead to metal-toxicity are not always clear, oxidative stress is often implicated as a major contributor of toxicity in bacteria [6].

To gain a better understanding of the role of metal ions in detoxification and as inducers of oxidative stress, we again used roGFP2 in $S$. Typhimurium. First, we investigated the involvement of metal ions in detoxifying enzymes by testing $\mathrm{H}_{2} \mathrm{O}_{2}$ detoxification in the presence of $25 \mathrm{mM}$ of metal chelators EGTA or EDTA (Fig. 6A). No inhibition was observed after addition of the specific calcium chelator EGTA whereas addition of EDTA (which is a nonspecific divalent cation metal chelator) dramatically reduced the activity of detoxifying enzymes. We then examined detoxification after addition of several alkaline earth metals or zinc $(1 \mathrm{mM}$ $\mathrm{MgCl}_{2}, 1 \mathrm{mM} \mathrm{CaCl}$ or $1 \mathrm{mM} \mathrm{ZnCl}$ ) and compared detoxification to a $1 \mathrm{mM} \mathrm{NaCl}$ control (Fig. 6B). Only addition of zinc ions inhibited activity of detoxifying enzymes significantly. In order to examine if zinc would directly affect the roGFP2 biosensor sensitivity, we tested the roGFP2 response of purified protein after addition of
$10 \mathrm{mM} \mathrm{H} \mathrm{H}_{2}$ and addition of zinc and compared these results to a saline control (Fig. S1A, Supplementary Material). No direct effect of zinc ions on roGFP2 sensitivity was observed. The effect of zinc on detoxification can be explained by the finding that zinc can replace iron in heme-binding catalases rendering the enzymes useless [46].

To directly examine oxidative stress resulting from the presence of alkali metals, we challenged hpxf S. Typhimurium with $1 \mathrm{mM} \mathrm{KCl}, 1 \mathrm{mM} \mathrm{LiCl}$ or $1 \mathrm{mM} \mathrm{RuCl}$, and compared the normalized $405 / 480$ ratio to a $1 \mathrm{mM} \mathrm{NaCl}$ control (Fig. $6 \mathrm{C}$ ). None of the alkali metals caused significant oxidative stress inside bacteria.

Secondly, we added alkaline earth metals $\left(1 \mathrm{mM} \mathrm{MgCl}_{2}\right.$ or $1 \mathrm{mM} \mathrm{CaCl}_{2}$ ) to this strain and compared the $\Delta 405 / 480$ ratio to a $1 \mathrm{mM} \mathrm{NaCl}$ control (Fig. 6D). Again, no significant increased oxidative stress was observed. Lastly, addition of several transition metals ( $1 \mathrm{mM} \mathrm{ZnCl} 2,1 \mathrm{mM} \mathrm{NiCl} 2$ or $1 \mathrm{mM} \mathrm{CoCl} 2$ ) showed that nickel (Fig. 6E) caused oxidative stress. In addition, we found that nickel ions did directly oxidize the roGFP2 biosensor (Fig. S1B, Supplementary Material) indicating that nickel contributes to formation of the disulfide bond in roGFP2. These results are in agreement with previous findings showing that nickel can cause spontaneous disulfide bond formation [47]. Based on these results we speculate that nickel contributes to oxidative stress through disulfide bond formation.

Together these results show that certain metal ions are required for $\mathrm{H}_{2} \mathrm{O}_{2}$ detoxification, whereas other metal ions contribute to oxidative stress by inhibition of detoxification (zinc) or by catalyzing formation of disulfide bonds (nickel).

\subsection{Antibiotics and endogenous ROS production}

Several studies have generated evidence to support the concept of oxidative stress as a general mechanism by which aminoglycosides, quinolones and $\beta$-lactam antibiotics kill bacteria [8-10]. An equal number of studies showed compelling data arguing there is no involvement of oxidative stress in bacterial killing by antibiotics [1113]. To investigate if antibiotics induce endogenous ROS formation, we used roGFP2 in hpxf $S$. Typhimurium and monitored the intrabacterial redox balance for 10hours following exposure to antibiotics. First, we added the aminoglycosides gentamicin, kanamycin and streptomycin and monitored the intra-bacterial redox balance (Fig. 7A). Interestingly, decreased endogenous ROS formation was observed compared to a control experiment in which no antibiotics were added. Additionally, exposure to ciprofloxacin (quinolone) and
A

\section{Aminoglycosides}

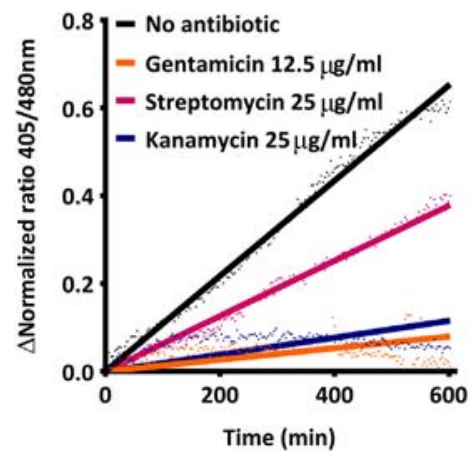

B

\section{Cephalosporins and} quinolones

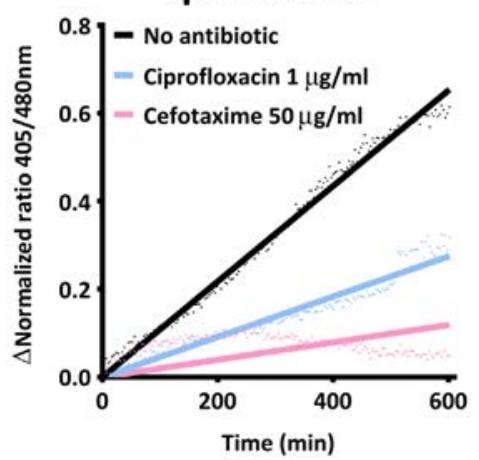

C

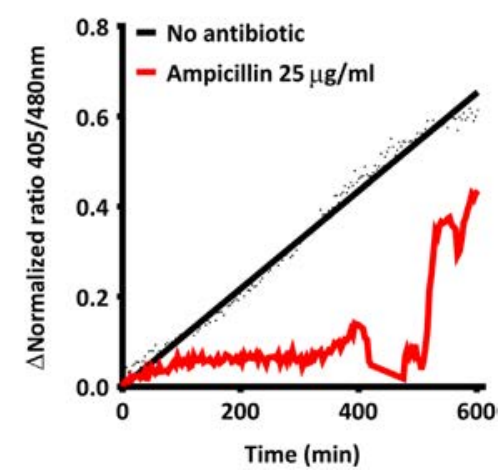

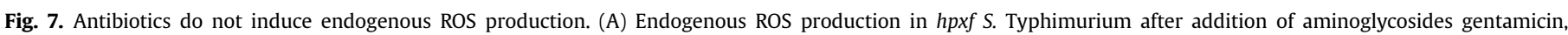

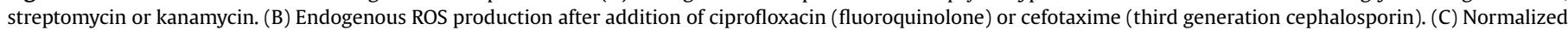

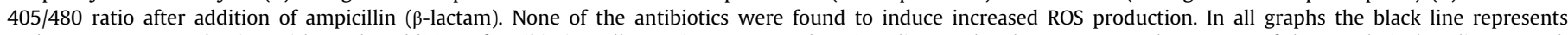

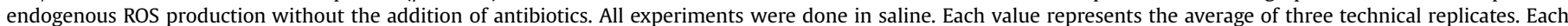
assay was performed in at least two separate experiments. 
cefotaxime (cephalosporin) did result in decreased ROS production (Fig. 7B). Lower levels of endogenous ROS formation indicated that the rate of respiration was decreased by exposure to antibiotics. Lastly, we monitored the intra-bacterial redox balance after exposure to ampicillin ( $\beta$-lactam) and found strong fluctuations in the intrabacterial redox balance starting $400 \mathrm{~min}$ after exposure (Fig. 7C). These fluctuations can be explained by the membrane disruption of $\beta$-lactam antibiotics despite the fact that the plasmid containing roGFP2 also carries ampicillin resistance. Since the experiment happened in saline without additional nutrients, no ampicillin resistance could be generated and under these conditions membrane disruption by ampicillin still occurred. In order to examine wether decreased production of endogenous ROS is not due to bacterial killing, we measured bacterial survival after exposure to the antibiotics used in this study (Fig. 3 in Ref. [40]). The antibiotics kanamycin, cefotaxime and ampicillin induced no significant killing under the conditions that were used in this experiment. The antibiotics gentamicin, streptomycin and ciprofloxacin induced only minor amounts of killing indicating that bacterial killing is not the reason behind reduced endogenous ROS production. Taken together, these results showed no induction of oxidative stress by any of the antibiotics tested in these experiments.

\section{Conclusions}

Encounters with oxidative stress-inducing conditions are commonplace for bacteria living with oxygen, and can affect respiration, bacterial replication, cell death etc. Since many critical cellular processes are directly affected by oxidative stress, it is unsettling that we still understand so little about redox dynamics inside living bacteria. We have now successfully used roGFP2 as a redox biosensor for the study of redox dynamics inside gram-negative bacteria in real-time. Using this analytical tool, we were able to compare the detoxifying power of several strains and found substantial differences among closely related strains or species. This was most apparent for two S. Typhi isolates (TY2 and ISP1820) for which the difference can be explained by the loss of $r p o S$ in the TY2 background [48]. For many other strains tested in this study, differences were unexpected and our results help describe redox characteristics of these strains for the first time. We predict that roGFP2 can be used to better define redox characteristics in many other laboratory strains and clinical isolates, as well as environmental microbes.

Using roGFP2, we also measured how the intra-bacterial redox balance was affected by several environmental conditions. In the lab, this could be used to better characterize experimental conditions; a need illustrated by a recent study showing major differences in the oxidative levels of commercially available LB media [49]. Outside the laboratory, roGFP2 reporter strains can be used to assess the effects of toxic contamination in the environment or during water treatment. Our results show that the presence of nickel and copper can induce endogenous ROS formation. Previously, cobalt was also found to induce ROS formation [50] however, our studies did not reveal a role for oxidative stress in cobalt-toxicity. The rapid experimental determination of intrabacterial oxidative stress could help reveal the basis of toxicity for many compounds. In practise this may be of particular use in preparing the correct bacteria for bioremediation of contaminated soil or water.

In the clinic, oxidative stress plays an important role during infection by bacterial pathogens. Interestingly, our results show that $\mathrm{H}_{2} \mathrm{O}_{2}$ detoxifying enzymes in the pathogen $S$. Typhimurium perform fastest at $37^{\circ} \mathrm{C}$ which is the temperature in our body. We speculate that these enzymes specifically evolved their maximum velocity at $37^{\circ} \mathrm{C}$ to be optimized for colonizing the human host. A bacterial encounter with the host-generated oxidative burst was considered to have mostly antimicrobial effects. However, more recently it was reported that ROS can also benefit pathogens by regulating virulence or facilitating a growth advantage. Powerful examples include the finding that $S$. Typhimurium utilizes the host's oxidative burst to outcompete commensal microbiota in the gut [51]. This growth advantage is caused by active induction of ROS formation by $S$. Typhimurium that subsequently react with thiosulfate to form tetrathionate. A specific gene cluster in the Salmonella genome enables $S$. Typhimurium to use tetrathionate as a respiratory electron acceptor giving it an edge over commensal microbiota. Recently, using roGFP2, we also showed that $S$. Typhimurium uses specific virulence factors to evade oxidative stress during infection by preventing proper co-localization of ROS with the Salmonella containing vacuole inside macrophages [16]. Identifying and examining these intricate relationships requires reliable redox biosensors and we propose that the use of roGFP2 in bacteria will greatly aid our understanding of host-pathogen relationships.

A major ongoing debate that currently occupies many microbiologists is the potential involvement of oxidative stress as a general killing mechanism for certain antibiotics [8-13]. Using roGFP2, we were able to measure oxidative stress inside bacteria during exposure to aminoglycosides, fluoroquinolones and $\beta$-lactams; all of which have been called oxidative stress-inducing antibiotics. In our experiments, we did not detect oxidative stress after exposure to any of these antibiotics. In contrast, we found that most antibiotics actually diminished endogenous ROS formation indicating a decreased rate of respiration. These results are in agreement with a recent study showing that inhibition of the electron transport chain can induce tolerance to $\beta$-lactam antibiotics [52]. Only after exposure to ampicillin we detected fluctuations in the intra-bacterial redox balance. However, these fluctuations are most likely resulting from disruption of the bacterial cell wall after longer exposure, which is the main mode-ofaction of $\beta$-lactams. Since the cell well is at the hearth of all respiratory processes in bacteria, it is not surprising that disruption of the cell wall results in redox fluctuations. Thus overall our results do not indicate any induction of ROS formation by these antibiotics.

For the first time, we used roGFP2 in a variety of different gram-negative bacteria to assess and compare intra-bacterial redox dynamics in real-time. Our findings that no oxidative stress was induced by exposure to antibiotics, help solve a controversy that captivated many microbiologists for the past couple of years. Other uncertainties involving numerous heavy metals that were implicated in causing bacterial oxidative stress, were answered by confirming involvement of nickel and copper while countering the role of oxidative stress in cobalt-toxicity. Considerably dissimilar redox characteristics of closely related strains were previously unknown and our results contribute greatly to a better understanding of bacterial defenses and stress responses. The use of roGFP2 to reveal characteristics of $\mathrm{H}_{2} \mathrm{O}_{2}$ detoxification by bacterial pathogens will assist in characterization of host-pathogen relationships and have broad utility as a tool to study redox related virulence mechanisms. Taken together these results show that the roGFP2 biosensor can be used inside bacteria and can play a critical role in research that will eventually elucidate intricate relationships between oxidative stress and bacteria.

\section{Acknowledgments}

This work was supported by operating grants from the Canadian Institutes of Health Research (CIHR-27R18706). B.B.F. is the 
University of British Columbia Peter Wall Distinguished Professor. No competing interests exist for this work. We sincerely thank Dr. James Remington from the University of Oregon for providing the original pRSETB roGFP2 construct.

\section{References}

[1] F.C. Fang, Antimicrobial actions of reactive oxygen species, mBio 2 (5) (2011).

[2] P.A. Hyslop, et al., Hydrogen peroxide as a potent bacteriostatic antibiotic implications for host defense, Free Radic. Biol. Med. 19 (1) (1995) 31-37.

[3] M. Gutscher, et al., Real-time imaging of the intracellular glutathione redox potential, Nat. Methods 5 (6) (2008) 553-559.

[4] R.C. Fahey, Glutathione analogs in prokaryotes, Biochim. Biophys. Acta 1830 (5) (2013) 3182-3198.

[5] A. Vazquez-Torres, Redox active thiol sensors of oxidative and nitrosative stress, Antioxidants Redox Signal. 17 (9) (2012) 1201-1214.

[6] J.A. Imlay, Diagnosing oxidative stress in bacteria: not as easy as you might think, Curr. Opin. Microbiol. 24 (2015) 124-131.

[7] J.M. Slauch, How does the oxidative burst of macrophages kill bacteria? Still an open question, Mol. Microbiol. 80 (3) (2011) 580-583.

[8] M.A. Kohanski, D.J. Dwyer, J.J. Collins, How antibiotics kill bacteria: from targets to networks, Nat. Rev. Microbiol. 8 (6) (2010) 423-435.

[9] M.A. Kohanski, D.J. Dwyer, B. Hayete, C.A. Lawrence, J.J. Collins, A common mechanism of cellular death induced by bactericidal antibiotics, Cell 130 (5) (2007) 797-810.

[10] D.J. Dwyer, et al., Antibiotics induce redox-related physiological alterations as part of their lethality, Proc. Natl. Acad. Sci. USA 111 (20) (2014) E2100-E2109.

[11] Y. Liu, J.A. Imlay, Cell death from antibiotics without the involvement of reactive oxygen species, Science 339 (6124) (2013) 1210-1213.

[12] I. Keren, Y. Wu, J. Inocencio, L.R. Mulcahy, K. Lewis, Killing by bactericidal antibiotics does not depend on reactive oxygen species, Science 339 (6124) (2013) 1213-1216.

[13] B. Ezraty, et al., Fe-S cluster biosynthesis controls uptake of aminoglycosides in a ROS-less death pathway, Science 340 (6140) (2013) 1583-1587.

[14] L. Aussel, et al., Salmonella detoxifying enzymes are sufficient to cope with the host oxidative burst, Mol. Microbiol. 80 (3) (2011) 628-640.

[15] N.A. Burton, et al., Disparate impact of oxidative host defenses determines the fate of Salmonella during systemic infection in mice, Cell. Host Microbe 15 (1) (2014) 72-83.

[16] J. van der Heijden, E.S. Bosman, L.A. Reynolds, B.B. Finlay, Direct measurement of oxidative and nitrosative stress dynamics in Salmonella inside macrophages, Proc. Natl. Acad. Sci. USA 112 (2) (2015) 560-565.

[17] G.T. Hanson, et al., Investigating mitochondrial redox potential with redoxsensitive green fluorescent protein indicators, J. Biol. Chem. 279 (13) (2004) 13044-13053.

[18] J. van der Heijden, B.B. Finlay, In vitro real-time measurement of the intrabacterial redox potential, Bio-protocol 5 (17) (2015) e1579.

[19] A.J. Meyer, T.P. Dick, Fluorescent protein-based redox probes, Antioxid. Redox Signal 13 (5) (2010) 621-650.

[20] T. Jubany-Mari, L. Alegre-Batlle, K. Jiang, L.J. Feldman, Use of a redox-sensing GFP (c-roGFP1) for real-time monitoring of cytosol redox status in Arabidopsis thaliana water-stressed plants, FEBS Lett. 584 (5) (2010) 889-897.

[21] B. Morgan, M.C. Sobotta, T.P. Dick, Measuring E(GSH) and $\mathrm{H}_{2} \mathrm{O}_{2}$ with roGFP2based redox probes, Free Radic. Biol. Med. 51 (11) (2011) 1943-1951.

[22] P. Back, et al., Exploring real-time in vivo redox biology of developing and aging Caenorhabditis elegans, Free Radic. Biol. Med. 52 (5) (2012) 850-859.

[23] M.O. Breckwoldt, et al., Multiparametric optical analysis of mitochondrial redox signals during neuronal physiology and pathology in vivo, Nat. Med. 20 (5) (2014) 555-560.

[24] A. Bhaskar, et al., Reengineering redox sensitive GFP to measure mycothiol redox potential of Mycobacterium tuberculosis during infection, Plos Pathog. 10 (1) (2014) e1003902.

[25] M. Gutscher, et al., Proximity-based protein thiol oxidation by $\mathrm{H}_{2} \mathrm{O}_{2}$-scavenging peroxidases, J. Biol. Chem. 284 (46) (2009) 31532-31540.

[26] R.H. Valdivia, S. Falkow, Bacterial genetics by flow cytometry: rapid isolation of Salmonella typhimurium acid-inducible promoters by differential fluorescence induction, Mol. Microbiol. 22 (2) (1996) 367-378.

[27] M. Hebrard, J.P. Viala, S. Meresse, F. Barras, L. Aussel, Redundant hydrogen peroxide scavengers contribute to Salmonella virulence and oxidative stress resistance, J. Bacteriol. 191 (14) (2009) 4605-4614.

[28] S.K. Hoiseth, B.A. Stocker, Aromatic-dependent Salmonella typhimurium are non-virulent and effective as live vaccines, Nature 291 (5812) (1981) 238-239.

[29] O. Gal-Mor, D.L. Gibson, D. Baluta, B.A. Vallance, B.B. Finlay, A novel secretion pathway of Salmonella enterica acts as an antivirulence modulator during salmonellosis, Plos. Pathog. 4 (4) (2008) e1000036.

[30] T. Durfee, et al., The complete genome sequence of Escherichia coli DH10B: insights into the biology of a laboratory workhorse, J. Bacteriol. 190 (7) (2008) 2597-2606.

[31] F.W. Studier, B.A. Moffatt, Use of bacteriophage T7 RNA polymerase to direct selective high-level expression of cloned genes, J. Mol. Biol. 189 (1) (1986) $113-130$.

[32] W. Deng, et al., Comparative genomics of Salmonella enterica serovar Typhi strains Ty2 and CT18, J. Bacteriol. 185 (7) (2003) 2330-2337.

[33] C.G. Forest, E. Ferraro, S.C. Sabbagh, F. Daigle, Intracellular survival of Salmonella enterica Serovar typhi in human macrophages is independent of Salmonella pathogenicity island (SPI)-2, Microbiology 156 (Pt 12) (2010) 3689-3698.

[34] A. Iguchi, et al., Complete genome sequence and comparative genome analysis of enteropathogenic Escherichia coli 0127:H6 strain E2348/69, J. Bacteriol. 191 (1) (2009) 347-354.

[35] P.I. Tarr, et al., Iha: a novel Escherichia coli 0157:H7 adherence-conferring molecule encoded on a recently acquired chromosomal island of conserved structure, Infect. Immun. 68 (3) (2000) 1400-1407.

[36] W. Deng, Y. Li, B.A. Vallance, B.B. Finlay, Locus of enterocyte effacement from Citrobacter rodentium: sequence analysis and evidence for horizontal transfer among attaching and effacing pathogens, Infect. Immun. 69 (10) (2001) 6323-6335.

[37] K.A. McDonough, J.M. Hare, Homology with a repeated Yersinia pestis DNA sequence IS100 correlates with pesticin sensitivity in Yersinia pseudotuberculosis, J. Bacteriol. 179 (6) (1997) 2081-2085.

[38] S.D. Auweter, et al., Quantitative mass spectrometry catalogues Salmonella pathogenicity island-2 effectors and identifies their cognate host binding partners, J. Biol. Chem. 286 (27) (2011) 24023-24035.

[39] C. Kroger, et al., An infection-relevant transcriptomic compendium for Salmonella enterica Serovar typhimurium, Cell. Host Microbe 14 (6) (2013) 683-695.

[40] J. van der Heijden, et al., Investigating the relationship between oxidative stress, endogenous reactive oxygen species and bacterial survival, Data Brief (2015).

[41] L.C. Seaver, J.A. Imlay, Alkyl hydroperoxide reductase is the primary scavenger of endogenous hydrogen peroxide in Escherichia coli, J. Bacteriol. 183 (24) (2001) 7173-7181.

[42] L. Kussmaul, J. Hirst, The mechanism of superoxide production by NADH: ubiquinone oxidoreductase (complex I) from bovine heart mitochondria, Proc Natl. Acad. Sci. USA 103 (20) (2006) 7607-7612.

[43] K. Frick, M. Schulte, T. Friedrich, Reactive oxygen species production by Escherichia coli respiratory complex I, Biochemistry 54 (18) (2015) 2799-2801.

[44] V. Robbe-Saule, C. Coynault, M. Ibanez-Ruiz, D. Hermant, F. Norel, Identification of a non-haem catalase in Salmonella and its regulation by RpoS (sigmaS), Mol. Microbiol. 39 (6) (2001) 1533-1545.

[45] K.W. v. Nägeli, Über oligodynamische Erscheinungen in lebenden Zellen. (Gesellsch. Ges. Naturweiss, Bd XXXIII Abt 1., Schweiz), 1893.

[46] J.A. Imlay, The mismetallation of enzymes during oxidative stress, J. Biol. Chem. 289 (41) (2014) 28121-28128.

[47] S.A. Ross, C.J. Burrows, Nickel complexes of cysteine- and cystine-containing peptides: spontaneous formation of disulfide-bridged dimers at neutral $\mathrm{pH}$, Inorg. Chem. 37 (20) (1998) 5358-5363.

[48] V. Robbe-Saule, F. Norel, The rpoS mutant allele of Salmonella typhi Ty2 is identical to that of the live typhoid vaccine Ty21a, FEMS Microbiol. Lett. 170 (1) (1999) 141-143.

[49] B. Ezraty, C. Henry, M. Herisse, E. Denamur, F. Barras, Commercial lysogeny broth culture media and oxidative stress: a cautious tale, Free. Radic. Biol. Med. 74 (2014) 245-251.

[50] F. Barras, M. Fontecave, Cobalt stress in Escherichia coli and Salmonella enterica: molecular bases for toxicity and resistance, Metallomics: Integr. biometal Sci. 3 (11) (2011) 1130-1134.

[51] S.E. Winter, et al., Gut inflammation provides a respiratory electron acceptor for Salmonella, Nature 467 (7314) (2010) 426-429.

[52] J. Jones-Carson, et al., Nitric oxide from IFNgamma-primed macrophages modulates the antimicrobial activity of beta-lactams against the intracellular pathogens Burkholderia pseudomallei and Nontyphoidal Salmonella, Plos. Neglected Trop. Dis. 8 (8) (2014) e3079. 